\title{
Exploring the nature of myth and its role in science
}

\author{
W. BRUCE MASSE ${ }^{1}$, ELIZABETH WAYLAND BARBER ${ }^{2}$, \\ LUIGI PICCARDI ${ }^{3} \&$ PAUL T. BARBER ${ }^{4}$ \\ ${ }^{1}$ ENV-EAQ Ecology \& Air Quality Group, Mailstop 5978 Los Alamos National Laboratory, \\ Los Alamos,New Mexico 87545, USA (e-mail: wbmasse@lanl.gov) \\ ${ }^{2}$ Department of Languages and Literatures, Occidental College, 1600 Campus Road, \\ Los Angeles, California 90041, USA \\ ${ }^{3}$ CNR, Istituto di Geoscienze e Georisorse, Via G. La Pira, 4, 50121, Firenze, Italy \\ ${ }^{4}$ UCLA Fowler Museum of Cultural History, Box 954951, Los Angeles, \\ California 90095-1549, USA
}

\begin{abstract}
The scientific study of myth is dominated by a paradigm that recognizes myth as having been viewed as truthful narrative history by past traditional cultures and yet is considered false or otherwise suspect by the modern scholars who study myth. Although virtually all scholars recognize that myth was of critical importance for traditional cultures, the attempt to elicit scientific reasons for this importance has led to many competing theories, few of which place an emphasis on the validity of myths as representing the product of actual observed historical natural events. This paradox may hinder our understanding of the origins of myth and prevent us from fully appreciating a critical aspect of why myth was so highly valued by past cultures. To set the stage for our examination of the possible natural history core of myth, we discuss briefly the history of the western scientific study of myth, with an emphasis on geological sciences. We then explore the cognitive structure of myth and provide working principles about how the historical information contained in these myths can be transmitted faithfully through successive generations and can be elicited by scientific study. Although recognizing the extreme complexity of myth as a cultural product, our data indicate that a science-based natural history approach can lead to important insights regarding the nature of myth.
\end{abstract}

The modern study of myth is an important component of a number of academic disciplines in the social sciences and humanities including anthropology, art history, classics, comparative religion, folklore, psychology, and theology (Dundes 1984). Thousands of scholarly books and tens of thousands of articles and papers have been written about the topic of 'myth' and its study. The roots of myth go back in time to the very dawn of human history, and it is clear from the popularity of recent television shows such as Xena, and blockbuster movies such a Star Wars and the Lord of the Rings that myth continues to be a robust part of contemporary popular culture.

Despite such popularity, the study of myth is beset by a tangled web of claims and contradictions. Although there are some generally accepted notions of what constitutes a myth, most scholars note that there is no universally accepted definition of the term, nor is there a consensus view of its nature and how it should be studied.

Most typically, myths, along with legends and folktales, are viewed in the context of a division of orally transmitted prose or poetic narrative into three often overlapping components (e.g. Bascom 1965). Folktales are non-religious fictional stories meant to entertain, although they often teach a practical lesson or draw a moral. They are also nonhistorical in that they are not set in any particular place or time. Folktales should not be confused with the term 'folklore', the latter representing folktales and other creative verbal expressions (including also myth and legend) that are studied by folklorists using literary and ethnological techniques.

'Legend' and 'myth' are largely synonymous terms, as is evident in the various contributions contained in this volume. Legends for the most part are semi-historical stories believed true by the cultures in which they are told. They serve to establish local customs, recount the migrations of people, and account for the deeds of heroes. Legends typically combine realism with supernatural and mythic elements. Epic narratives are lengthy stories that often cross the boundary between legend and myth, often told in poetry or rhythmic prose or chant, the telling of which can last for hours or even days. Most traditional cultures had epics, 
among the more famous of which are the Greek Iliad and Odyssey, the Icelandic Edda, the Hindu Mahabharata, and the Hawaiian Kumulipo genealogical chant.

Myths are cultural accounts of major events that typically happened in the remote past of that culture, when the world was different to today. They are considered truthful by the traditional knowledge keepers who transmit the stories, and mostly are profoundly sacred or at least are imbued with strong religious and ritual overtones. Myths use supernatural characters (gods, demigods or animals) and storylines to express the limits and workings of the world and the place in nature of one's cultural group-the latter also being a general concept commonly referred to as one's 'world view'. Anthropologist William Haviland (1975, p. 337), perceptively, stated that 'The concepts of world view and science are intimately related, and it may be said that myth is the science of cultures which do not verify 'truth' about nature by means of experiment'. The fact that virtually all traditional knowledge keepers believe myths (and legends) to be historically true whereas nearly all scientists presume they do not represent factual historical events is a disquieting conundrum that tells us more about the biases of western science than the nature of myth.

The great diversity of the scholarly works on myth shows that, although being one of the most studied subjects in the history of the social sciences and the humanities, it has not yet been entirely understood. At the crux of this confusion is the simple and straightforward question of whether or not the storyline content of myth has any basis in historical events or processes.

A disdainful view of myth is easily demonstrated by a simple citation analysis of the editorial use of the term 'myth' in headers for articles and reports (none listed), and other sections (such as book reviews, correspondence, and research news; a total of ten cases) in the generally well-respected journals Nature and Science during the ten-year publication period of 1996 through 2005. Both the infrequency of the use of the term and its implied meaning are striking. The few times that 'myth' is used are virtually always in a pejorative sense, such as 'time to bury misleading myth', 'dispelling a myth', and 'making reality fit the myth'. The two occurrences of the term in Science in 2005 ('Sifting myths for truths about our world', May 27; and 'Tracking myth to geological reality', November 4) defy this trend in that they specifically refer to work included in or written by authors of the present Myth \& Geology volume.

It can be demonstrated beyond any doubt that at least some myths and categories of myth are based on the observation of specific real natural phenomena and events that can be accurately placed in both space and time and can be linked to various types of physical evidence for the historical event. That we can make such unquestionable matches is because pertinent myth storylines contain rich details about the natural events and phenomena, and that one can find unambiguous confirmation and field evidence of their factual occurrence in the places indicated in the account. These accounts also appear to have structural rules and principles that shape the content and oral transmission of myth.

In this paper, we briefly explore past scientific notions of myth and attempt to provide a somewhat different conception of those myths whose roots appear to lie in the observation of natural phenomena and events, in particular geological events. This perspective is slanted toward western science and the myths of western civilization. Throughout Asia and the Indian subcontinent, myth and science evolved together much more parsimoniously in that myth was never considered as being entirely separate from history (e.g. Lowe \& Shaughnessy 1999, pp. 11-13; Chandrasekharam). For example, the sceptical contempt currently attached by western scholars and historians to China's admittedly fragmentary and reconstructed Bamboo Annals (Legge 1994, pp. 105-188), with its striking mysterious and supernatural rulers and culture heroes, might change in the face of an analysis viewed in the context of its traditional roots and with our suggested framework by which to view its mythic content (see also Masse 1998). Certainly the encouraging results of the past several decades of dedicated research expended on identifying the realities of geophysical processes and events in the Bible (e.g. Greenberg 2005; Roberts; Trifonov) should serve to underscore the rich potential of Asian and Indian historical religious texts.

Because many geologists are largely unfamiliar with the multidisciplinary science of cognition, we summarize basic deductions regarding the cognitive structure of myth that subjected myth to systematic (but reconstructible) distortions through time, and then show that the traditional transmission of myth was generally efficient and conservative. We also discuss how celestial and Earth phenomena and events make up a large portion of myth storylines. Our focus here is on myth in geology, or geomythology (sensu Vitaliano 1973, and this volume), which we define as 'the study of the geological origin of myths and legends'. Astronomy shares with the Earth sciences a kindred relationship in that both can be used not only to demonstrate the reality of many myths but also to serve as vehicles by which to mine myths for important information about these natural processes and 
events (Masse 1995; Masse \& Espenak 2006; Masse et al. 2007).

\section{An overview of past and present scientific trends in the study of myth}

Scholars and scientists have puzzled over the nature and meaning of myth since the beginnings of western science more than 2500 years ago, as evident in a sampling of recent literature on the topic (Dundes 1984; Veyne 1988; Patton \& Doniger 1996; Brisson 1998; Naddaf 1998; Lincoln 1999; Doty 2000; Schrempp \& Hansen 2002). There are far too many scholars, theories, and permutations of theories in the history of the study of myth to do more than provide a brief overview of general trends through time, focusing on those aspects that best serve to highlight our own emphasis on the historical content of myth.

The term mythology stems from the Greek mythos - 'word' or 'story' - and logos, a term that also meant 'word' in the sense of speaking (from the verb legein 'to speak'). Thus Greek mythologia appropriately meant '[speaking] words about stories'. The ancient Greeks had plenty of things to say about myth (e.g. Brisson 1998; Veyne 1988; Kirk 1974; Graf 1993). Plato considered myth and poetry, such as Homer's Iliad and Odyssey and Hesiod's Theogony and Works and Days, to be a linguistic art form, and he often debunked the truth claimed for portions of myth storylines. His main criticism is philosophical in that because myth existed in the context of oral tradition, it was therefore 'unfalsifiable' (Naddaf 1998; Brisson 1998). Plato suggested that one could understand the secrets of the gods by etymological interpretation of their names and epithets, and that the concept of gods originated when people began to observe the regular movement of the fixed celestial heavens. However, Plato's scorn for the historical reality of myth storylines did not prevent him from mentioning the particulars of several myths and thus perpetuating them, perhaps most notably that of the infamous destruction of Atlantis.

Early Greek historians such as Herodotus used the term mythos in a derogatory manner to denote false or 'very silly' stories, but still faithfully reported a number of other orally transmitted stories as having merit. He championed the notion that the Greek gods were borrowed from a variety of other cultures, and that interpretations of the names of these other gods and their attributes demonstrated this connection. Thucydides took this derision of myth a step further and denounced all oral tradition (including that used by Herodotus) because of its reliance on memory for its transmission. Later Roman historians continued such rhetoric and polemics through the fourth and fifth centuries AD (Rohrbacher 2002). Roman historians specifically coined the term fabulae with respect to myths, from which are derived the modern terms fable and fabulous. This is a clear indication that most Roman historians did not consider myth to represent factual history.

Among the more interesting historical theories of myth was that expressed in the writings of the novelist Euhemeros and echoed by Herodotus and Prodicus, who suggested that the gods were all once living people whose significant deeds became glorified and distorted through time so that their human origins became forgotten. The term 'euhemerism' has been applied to this theory by modern scholars of myth. A similar but still distinct theory was advocated by Palaephatus, a possible contemporary of Aristotle, who provided rationalizations for a number of stories about early heroes and monstrous creatures (Stern 1996). Palaephatus (1996, p. 29) states:

Now some people, who have no acquaintance with philosophy or science, are too credulous and believe everything that is said to them. Others, of a more subtle and inquisitive nature, totally disbelieve that any of these tales ever happened. My own belief is that there is a reality behind all stories.

Palaephatus uses a number of different types of rationalization (e.g. confusion of human and animal names; puns and double meanings; misunderstood metaphorical expressions) to explain these stories, only a few of which actually relate to natural (e.g. geological) events and phenomena. Unfortunately, despite his claims, it is not possible to judge the actual historicity of the rationalizations by Palaephatus.

Other early theories in antiquity about myth included the likelihood that allegory portrays spiritual qualities and natural phenomena; sociological explanations involving priests and rulers inventing deities with fearful powers so as to maintain social order, popularized by the sophist Critias; and various psychological interpretations (Honko 1984).

Between the time of Plato in the fourth century $\mathrm{BC}$ and the Renaissance of the AD 1300-1600s, myth was largely ignored, being replaced by a rigorous adherence to biblical scriptures and text. The rediscovery during the Renaissance of ancient classical texts and the discovery of the New World led to a new exposure to worldwide myths, but the Bible was still the standard against which all new myth from other cultures was weighed.

During the first half of the eighteenth century Enlightenment, considerations of myth were largely divided into three main camps (Feldman \& Richardson 2000). For Christians, the Bible 
was 'gospel truth' whereas myth consisted of pagan fables and religion. Deists tended to include Biblical tradition within the rubric of fables in their search for an initial pure primal religion. Rationalist views, such as by Voltaire, Hume, and Fontenelle, tended to dismiss myth as savage or foolish, and an example of primitive approaches to explanation of the natural world.

Because of the current prevalence of psychological and structural models of myth in the social sciences, it might be anticipated that most modern theories of myth arose during the rise of modern anthropology and psychology in the nineteenth and early twentieth century. In fact, most of these theories had their roots in eighteenth century Enlightenment rationalism and deist thinking (Manuel 1959; Feldman \& Richardson 2000). An example is Bernard Fontanelle's precocious but depreciative essay on the origin of fables (i.e. myths), originally written in the 1690 s. While avoiding religious polemics, his studies anticipated the comparative psychological approach to mythology. Fontanelle (2000) suggested that primitive ignorance of natural processes and events led to the formation of some myths, and attempted to demonstrate that principles of myth were due to universal mental processes that were separate from climate and the passage of time. Many other Enlightenment scholars contributed to an upsurge of interest in myth. These included David Hume, who focused on the psychological origins of religion and myth; Christian Gottlob Heyne, who drew attention to philological aspects of myth, separating it from poetry but pointing out the effects of poetry on mythology; and Johann Gottfried Herder, who put the empirical study of myth centre-stage in the humanities.

During the late 1700s and early 1800s, Romanticism swept through Europe (Manuel 1959; Feldman \& Richardson 2000). It began in Germany (e.g. Friederich and August Schlegel, Wilhelm and Jacob Grimm) and then on to England (e.g. Keats, Shelley, Coleridge, Byron), France (e.g. Chénier, Balzac, Hugo, Michelet), and finally the Americas (e.g. Emerson, Thoreau, Whitman). Myth assumed a 'larger than life' importance during the Romantic era. Knowledge of myth from the Indian subcontinent (e.g. Hindu myth), Egypt, American Indians, and Polynesia coupled with the expansion of philology greatly stimulated the nascent disciplines of culture, language and history. Romantics viewed myth as having a religious quality, allowing modern men the ability to redeem themselves and return to an earlier simplistic relationship between God and nature. For example, the early work by the brothers Grimm with folktales ('fairytales') was an attempt to glean German folklore in order to find mythic evidence of an earlier Germanic heroic period comparable to that of early Greece. It was their assumption that the oldest German history and its associated spiritual forces could be reconstructed from German folklore. Similar efforts were made by other scholars in other countries, thus leading to the use of myth by which to promulgate and glorify nationalism.

During the nineteenth century, the retelling of classical myths became fashionable. Notable was the Wonder Book for Boys and Girls by Nathaniel Hawthorne, The Heroes by Charles Kingsley, and The Age of Fables by Thomas Bulfinch which were all originally produced in the $1850 \mathrm{~s}$ (Feldman \& Richardson 2000). These and similar anthologies bowdlerized the myths, using Victorian prose and sentiment to turn them essentially into nonsense stories

The modern study of mythology is often attributed to the work of (Friedrich) Max Müller in the latter half of the nineteenth century. Müller was an extraordinary philologist whose mastery of ancient and modern languages was phenomenal. He hypothesized that similar to Latin being the forerunner of modern romance languages, 'Aryan' was the forerunner of Greek, Latin, Sanskrit, Zend, Celtic, and Gothic (Feldman \& Richardson 2000). The Aryan language of this earliest 'mythopoeic era' was incapable of abstraction, therefore descriptions of the actions of the living Sun (myths) were substituted for our common terms such as sunrise and sunset. After the end of the mythopoeic era and the creation of new nations and languages, the old words describing the actions of the Sun remained in vocabularies but their origins could no longer be understood. Thus degenerated stories (new myths) were created as explanatory devices. Comparative mythology took the form of studying myths from related cultures to attempt to work back in time through this 'disease of language' (as earlier coined by Friedrich Schelling) so as to uncover the original pure myths and their meanings.

Müller's 'solar mythology' fell completely out of favour towards the end of the nineteenth century, with his philological approach to comparative mythology being replaced by more fashionable comparative anthropological, sociological and linguistic/symbolic approaches (Dorson 1955; Lincoln 1999). These late nineteenth and early twentieth century scholars included E.B. Tylor, Andrew Lang, Sir James George Frazer, Émile Durkheim, Marcel Mauss, and Arnold van Gennep. They perceived myths as being embedded in oral rather than textual traditions, to be studied in association with ritual performances and certain social constructs, rather than solely in the context of language and literature. 
The modern twentieth century theories of myth that evolved from this post-Müller intellectual milieu can be divided into four general but not necessarily mutually exclusive categories (Honko 1984; see also Lincoln 1999; Doty 2000). The first is that of the 'psychological school' of myth, initially deriving from Freud's analysis of myths, but more recently allied with Jung's view of the presence of universal archetypical motifs and complexes. More recent notable practitioners include Mircea Eliade and Joseph Campbell. Myth variously serves as a source of cognitive categories; as a form of symbolic expression; as a projection of the subconscious; and as an integrating factor in our adaptation to life or world view. The Hungarian classical scholar, Carl Kerényi, who worked closely with Jung, glimpsed the possibility that natural processes (such as Moon phases) could have an influence on myth and cosmology, in contradistinction to Jung (Kerényi 1993). However, Kerényi focused on observed cosmic processes as opposed to specific natural (e.g. geological) events as being the source of 'mythologems' or recurrent themes of myth (Jung \& Kerényi 1993).

Joseph Campbell is perhaps best known proponent of the psychological school of myth, which in one form or another likely includes most current folklorists and anthropologists. His approach to myth is perhaps best stated in response to the question of why people tend to use the word 'myth' to mean something that is untrue or an erroneously held belief (Campbell 1989, p. 21):

I can understand why that idea arose. Myth is metaphor. The imagery of mythology is symbolic of spiritual powers within us: when these are interpreted as referring to historical or natural events which science in turn shows could not have occurred, then you throw the whole thing out.... Myths come from where the heart is, and where the experience is, even as the mind may wonder why people believe these things. The myth does not point to a fact; the myth points beyond facts to something that informs the fact

The second school of myth, the 'sociological' or socio-functional, derives from Durkheim's view that myths arise in the human response to social existence. They mirror the manner in which society represents the world and humanity, and serve as a moral system and cosmology, and as history. Myths and their associated rituals renew human belief systems and strengthen social ties. Durkheim rejected the notion that myth arises out of extraordinary manifestations of nature. Rather, myth serves as a charter of behaviour; as a legitimization of social institutions; as a marker of social relevance; and as a mirror of social structure and culture. More recent adherents to the sociofunctional school of myth include Bronislaw Malinowski and Anthony F. C. Wallace.
One of the more interesting and comprehensive theories popularized during the twentieth century is that of the structural analysis of Claude Lévi-Strauss, which constitutes our third school of myth (Lincoln 1999; Doty 2000). 'Structuralism' descends from the nineteenth century synchronic structural linguistic theories of Ferdinand de Saussure, along with the more recent rational and patterned organizational approach of Georges Dumézil in the early to mid-twentieeth century. Lévi-Strauss was interested in explaining why myths from cultures around the world have so many striking similarities. He favoured studying the structure of myth rather than its content. He considered that myths are made of units that are put together according to certain structural rules, and that these units form relationships with each other, based on binary opposites. The ahistorical (or even antihistorical) approach of Lévi-Strauss (1969, p. 240) is well captured in the following observations from his study of South American myth:

In granting that myths have an astronomical significance ... the astronomical context does not provide any absolute point of reference; we cannot claim to have interpreted the myths simply by relating them to this context. The truth of the myth does not lie in any special content. It consists in logical relations which are devoid of content, or, more precisely, whose invariant properties exhaust their operative value, since comparable relations can be established among the elements of a large number of different contents.

The fourth of these defined schools of twentieth century myth has been termed 'historical' (Honko 1984) although we would suggest that a more salient term would be 'historical context'. This school does not actually consider the potential historical content of myth but rather the impact of the social and historical environment in which myth is told. From this point of reference, myth serves as the result of a historical situation; as religious genre; and as religious communication.

A number of useful recent edited volumes (e.g. Patton \& Doniger 1996; Schrempp \& Hansen 2002) and syntheses (e.g. Lincoln 1999; Segal 1999; Doty 2000; Von Hendy 2002) regarding theories of myth in the social sciences and the humanities have attempted to characterize these general theories and their proponents, and to bring them forward through the end of the twentieth century into our era of semiotics, hermeneutics, deconstruction, and postmodernism. These have one fundamental shared characteristic-none is seemingly willing to suggest that a real observed natural process or event may lie at the core of myth storylines, other than perhaps as an aside to their overall theories. Even the degenerative or transformed history of Euhemeros, still popular in the nineteenth century, is no longer viewed as a viable theory by most scholars of myth (Alan Dundes, pers. comm. 2005). 
There are important exceptions to the general statement that most modern theories of myth lack consideration of the historical observation of natural process as being part of the myth storyline. These exceptions represent the potential contribution of the physical and cognitive sciences and our own nascent theoretical school of geomythology, as expressed by Dorothy Vitaliano (1973) and various indigenous scholars who know and understand the value of their own myths (e.g. Deloria 1995), and of course by the many contributors to this volume.

\section{Geology and myth}

As we have seen, the study of myths is an extremely complex and faceted subject, and much effort has been devoted to its understanding. Many authors have, since antiquity, recognized the potential historical value of myths. A large part of Greek myth is now known to be politico-religious history. The destruction of Troy described in the Iliad was finally recognized to be real history only in 1870 , when Heinrich Schliemann unearthed the ruins of ancient Ilion. Also, among many other examples, the history of Theseus killing the Minotaur in the Palace of Cnossos, is commonly regarded as a refracted image of the historical final defeat of the Minoan power in the Aegean region (c. 1400 BC). Similarly, at Delphi, the slaying of the snakedragon Python who guarded the sacred chasm of $\mathrm{Ge}$, the Earth, by Apollo, and the consequent shift of ruler of that famous Oracle, has been suggested as a description of the religious passage from the feminine cults of the matrilineal system to the more patriarchal deities.

An example that can serve to illustrate the historical reality lying behind the mythological narration is provided by the famous combat between Heracles and the Hydra of Lerna. The analysis of this famous story deserves some attention because it can provide useful insight regarding the origin and factual basis of a myth, as well as other mechanisms of myth-making (see Piccardi 2004).

The slaying of the Hydra has been one of the myths most widely considered, since antiquity, to rest on natural processes. The always regenerating many heads of the Hydra have been interpreted as a symbol of the many water-sources feeding the large swamps near Lerna, and the struggle between Hercules and the monster therefore an image of the draining effort. After finally chopping her main 'head', said to be immortal, the hero buried it forever, putting a huge and heavy rock on it. Kirk (1974), following an interpretation first proposed by Palaephatus, maintains instead that this myth more likely records ancient political events. In a manner similar to the killing of the Minotaur in the Palace of Knossos, the killing of the
Hydra at Lerna, as well as the related myth about the killing of the Nemean lion (the first two labours of Heracles, the Mycenaean hero), seems to contain memories of ancient political events in addition to references about fertility rites.

Strong connections are known to have existed between Lerna until the Early Bronze Age (Lerna III), and the Cretan civilization. The end of Lerna III was in part evidently due to the invasion of the Indo-European Greeks in $c .2200$ BC. These patriarchal Indo-European-speaking invaders, from whom later the Mycenaeans would originate, marked the end of the Early Bronze Age in many areas of the East Mediterranean. According to typical Minoan settlement patterns, the political and religious centre and the 'head' of the local community, would have been the Palace of Lerna ('House of Tiles'). The destruction of the Lernean Palace (2300-2200 BC) is marked by the peculiar singularity, seemingly unique in the whole of Greece, that the Palace was buried by the conquerors under an enormous funerary tumulus (e.g. Caskey \& Blackburn 1997), considered nevertheless an enigma by archaeologists because it contains no tombs.

This unusual tumulus, deliberately positioned above the 'head' of the defeated society, strictly corresponds to the huge mythological rock placed by Heracles above the head of the beast (Piccardi 2004). As such, the facts described by tradition largely coincide with what can be observed on the site. Even the position of the buried Palace, corresponds to the location of the head of the Hydra, buried in the myth on the side of the road to Elaeus. The mythological account can therefore be regarded as quasi-historical, recalling an Early Bronze Age phase of the Mycenean conquest of the Greek mainland against the Lernean Minoan related settlement. The seeming truth behind the myth, and the relevance of the tumulus itself, apparently was already forgotten by the end of the Middle Helladic period ( $c$. eighteenth-seventeenth century $\mathrm{BC})$, as indicated by the fact that the tumulus was then reoccupied by the village after being left untouched for nearly 500 years. We can thus consider this date as the moment when the local historical memory transmitted by oral tradition became a new myth as transmitted by Hesiod, Ovid, Apollodorus and other ancient writers, because the politico-religious factual story lying behind the myth had been forgotten.

Western scientific thought started at the turn of the sixth and fifth centuries BC, with Greek philosophy. As discussed by Karl Popper (1972), what was new then, was a new attitude toward the myths, jealously preserved by priests:

In place of a dogmatic handing on of the doctrine we find a critical discussion of the doctrine .... Doubt and criticism now become, 
in their turn, part of the tradition of the school. ... It is only in the course of this critical discussion that observation is called in as witness. ... On the other hand, ... the task which science sets for itself [that is the explanation of the world] and the main ideas which it uses, are taken over without any break from prescientific mythmaking.

Geology is a relatively young discipline. The term 'geology' was used for the first time by Richard of Bury, Bishop of Durham, in 1473, to indicate jurisprudence as 'terrestrial' doctrine as distinct from theology. The term gains a meaning nearer to the actual one with the pioneering works of Agricola (Giorgio Bauer, 1494-1555), Ulisse Aldovrandini (1522-1605) and Stenone (Niels Steensen, 1638-1686). It was with James Hutton (1726-1797) and his book Theory of the Earth (1795), Abraham G. Werner (1749-1817) and Charles Lyell (1797-1875), with Principles of Geology (1830-33), that geology attained the rank of a science.

Before geology became a recognized science, and for a long time after (through the first half of the nineteenth century), canonical belief regarding the nature and origin of the universe was as described in the Bible. An interesting summary of the conflict between religion and science and of the evolution of the scientific thought in recent times is given by the extensive work of White (1898), and can be found in Roberts.

In particular Noah's flood was considered a scientific truth, and was invoked as explanation for many geological phenomena, such as the finding of fossil shells on high mountains and the formation of moraines and other young sedimentary deposits. It was only in 1840 , with the recognition of the theory of glaciations proposed by Louis Agassiz (see Berger), that geology finally separated from the literal biblical view. On the other hand, the development of comparative mythology, by recognizing the similarity and derivation between the biblical narrations and other world mythologies, in particular from the Middle East and Mesopotamia, helped to circumvent the dogma of biblical 'truths'. Fundamental to this aim was the discovery and translation of the Mesopotamian account of the deluge (the Gilgamesh epic) in 1872. Biblical catastrophism was thus surpassed in favour of the modern theory of uniformitarism. (See Masse 1998, 2007 for the surprising results of a recent comparative mythology and environmental archaeology analysis of the flood myth).

There is evidence that, from the Palaeolithic, for more than 30000 years, a principal divinity may have been the Great Mother Goddess, alleged Lady of Life as well as of death (see Goodison \& Morris 1998, for a recent balanced treatment of this concept). Seemingly, rituals and cults were not directed so much upwards, to the celestial heavens, but rather downwards, to 'Mother Earth'. For example, archaeology and ethnographic literature document the ritual placement of various kinds of offerings (including occasional human sacrifices) into trenches, natural crevasses, volcanic craters, wells and other holes in the ground. Fissures and caves have been of special importance worldwide to past cultures (e.g. Piccardi 2000; Aringoli et al.). It is not surprising therefore that much attention would have been paid to geological phenomena, and in particular those more connected with the underworld, such as volcanoes and earthquakes. Such impressive phenomena, which aroused awe and wonder, likely would have been linked cognitively to the 'womb' of Mother Earth. Regardless of the merits of such an argument (e.g. for a differing view of early deities see Hodder's (2006; Balter 2004) research at the Neolithic town of Çatalhöyük), it is clear from the pantheons of new divinities, both male and female, appearing from the fifth to the second millennium $\mathrm{BC}$ that the geophysical forces of nature were well represented among the attributes of these deities and demigods.

In a similar vein, geological phenomena and events have likely always played a central role in myths because of their critical importance to traditional cultures. Stability of the landscape and climate were expected. Water was the primary source for life, so that springs, rivers and lakes attained special consideration. Caves were among the first dwellings of men during the Stone Age (... brush shelters were also used but do not well preserve in the archaeological record), and stone was a primary material for making tools. Rocks, such as flint and obsidian, were particularly valued for their cutting and visual properties (Hodgson) and large scale trade of these stones was developed and perpetuated. Huge fossils bones were interpreted as remains of giants or dragons (Agnesi et al., Berger, and Mayor). Other fossils attracted some sacredness and were incorporated into sacred architectures (McNamara) or venerated on altars (Chandrasekharam). Mythical explanations are also typically found for meteorites (D'Orazio and Masse \& Masse).

Myths were also created to explain unusual landscape features and natural landmarks, and were commonly prompted by mountains, rocks and boulders seeming to be out of place. Examples of these latter are described by Motta \& Motta and many similar cases are known elsewhere in the world. Ancient sacred lore abounds in such mythical explanations for the remarkable appearance of certain natural geological formations and structures.

In recent years there is an increasing awareness, at least among geologists, that some legends and myths are based on natural phenomena and that, by using a multidisciplinary approach, there is the 
possibility of identifying records of past geological events in particular narratives (e.g. Vitaliano 1973; Bentor 1989; Guidoboni 1989; Nur 1991; Vogt 1991; Ryan \& Pitmann 2000; Ryan 2004; Piccardi 2000, 2005; Ludwin et al. 2005).

One of the more useful applications of geomythology includes the possibility of adding to the historical record on natural catastrophes, thus helping their hazard mitigation. Several of the most damaging geophysical catastrophes like earthquakes, tsunamis, volcanic eruptions or meteorite impacts, were probably recorded in myths, for two reasons: first because they were very unusual and mysterious phenomena, and, second, because their impact on local societies made them important events to be remembered. Various examples of mythological accounts of such catastrophic events are presented in this volume.

Probably the best known example concerning volcanic eruptions is found in the myth of the destruction of Atlantis, interpreted as a refracted image of the supereruption of the Thera volcano around 1625 BC (Friedrich et al. 2006; Manning et al. 2006). Similarly, the fight between Titans and Olympians, and the imprisonment of Typhoon under the volcano Etna, has been interpreted as a memory of some period of intense activity of Etna and other volcanoes in the Mediterranean (Wyatt 1996; Barber \& Barber 2005).

A biblical example related to earthquakes, analysed by Bentor (1989) and Nur (1991), concerns the crossing of the River Jordan and the consequent famous destruction of Jericho's walls (Joshua 3, 4 and 6). In this case, the location of the site where the events occurred, and the details described in the text, permitted the identification in this account of a strong earthquake which induced the collapse of the nearly vertical banks of the river, at the spot where it crosses the major strike-slip Jordan Valley Fault. The same phenomenon happened again in the earthquake of 1546, when the water of the river was dammed and cut off for two days, and in the earthquakes of 1906 and 1927. The destruction of Jericho was listed as seismic event in a fifteenth century catalogue of earthquakes (Manetti 1457), and an earthquake link between the drying of the Jordan and the collapse of the walls of Jericho, was already recognized in antiquity (Psalm 114:3-8).

The most notable example of an important myth rooted in geology is the set of myths associated with the famous Delphic Oracle, in Greece, who continued her functions for almost 2000 years and whose influence spanned the ancient western world. The priestess was said to utter her oracles by inhaling vapours that arose from a chasm in the earth, above which she was seated. The existence of this sacred chasm had been dismissed by classical scholars as a mythological invention because no trace of it was discovered during modern archaeological excavations. Recent geological investigations have instead revealed that a natural gas-exhaling chasm in the earth indeed existed at the site of the oracle (Piccardi 2000; De Boer \& Hale 2000), although it may have closed prior to the modern era. The oracle site is in fact positioned directly across the surface trace of a seismic fault which potentially could rupture during earthquakes, thus creating a fissure in the ground from which gases like carbon dioxide, hydrogen sulphide, or methane could originate. De Boer et al. (2001) and Spiller et al. (2002) have determined the modern presence of ethylene (ethene), although the ancient presence of other gases such as those previously mentioned is also possible at various times through the long history of this location. An earthquake, albeit clothed in mythological images, is described at the origin of the Oracle in the Homeric Hymn to Apollo, coincident with the slaying of the snake-dragon. It is reasonable to assume that other oracle locations in Greece and elsewhere may have similarly originated due to the presence of emitted gases.

Further examples of legendary earthquakes are provided by the myths of the apparitions of Archangel Michael at Colossae (AD 60, Piccardi) and at Monte Sant'Angelo (Piccardi 2005). The legend of the apparition of Archangel Michael at Monte Sant'Angelo (traditionally dated AD 490-3) distinctly reports a large earthquake, described as an 'immenso tremore', affecting the area. A sanctuary, still existing today, was built where the 'footprints of the Archangel' were claimed to have been discovered, on the day after the main shock, in the epicentral area. Through use of a multidisciplinary approach, combining palaeoseismic and historical data, the legend can be demonstrated to represent a seismic surface faulting event before the eighth century AD. A recent, small scarp about $1 \mathrm{~m}$ high, on the Monte Sant'Angelo fault, can be related to this legendary earthquake which in turn seems to correspond to the local maximum magnitude $(M=6.7)$. The comparison of palaeoseismic evidence with the traditions of the sacred site and the evolution of the sanctuary has allowed the interpretation that the famous 'footprints' apparently were secondary ground ruptures related to surface faulting on the nearby local active fault (Piccardi 2005). The description of a strong earthquake at Monte Sant'Angelo is reported in two distinct legends. The two legends show remarkable similarities in that both refer to the same sacred site, and point (although in different ways) to ground ruptures related to the earthquake. The main witness in both tales is the unnamed first Bishop of the near town of Siponto. These parallel 
legends may represent two different traditions based on the same natural event: a large earthquake that produced surface faulting along the nearby active fault.

\section{Toward a natural sciences conception of myth}

It is our task to weave these many disparate historical threads of myth into a meaningful conceptual tapestry that can be understood and appreciated by modern science. In order to do so, we must first recognize three interrelated aspects of the context and character of 'traditional cultures', that is those groups not heavily influenced by the patterns of western culture and scientific thought.

First and most important, traditional cultures were/are largely holistic. These groups do not normally segment their natural universe, society, and knowledge systems into separate and independent components. It is a system in which everything is interconnected to one degree or another. Religion, myth, economics, subsistence, governance, kinship, and the events and processes of the natural world are all tied together in intricate interwoven layers. Thus events and processes in the natural world shape or influence other aspects of society.

This contrasts with modern western society in which we take great pains to divide our world into a number of small separate niches. Religion is separate from science, and tends to be separate from systems of governance. The sciences are typically divided into social science versus physical science and the life sciences. These sciences are each divided in a number individual disciplines, which in turn are divided into subdisciplines. It is not surprising that such segmentation of knowledge hinders our attempts to understand past holistic societies and the myths associated with those societies.

The second aspect of traditional culture and knowledge systems that modern western science has trouble grasping is that in a holistic world, major natural events and processes happening on the Earth and in the sky tend to be viewed as having a life of their own related to but separate from human lives. For example, the sky is not simply the fixed celestial heavens of regularly moving and largely predictable stars, constellations, planets, Sun and Moon, but also is the abode of a large number of transient phenomena and events such as comets, novae, meteors and meteor storms, eclipses, auroras, and other such celestial and meteorological happenings. To the naked-eye observer, these are of differing motion, colour, size, duration, and location, often with associated real sensory physical characteristics such as the sounds of bolides and the suite of physical effects that accompany total solar eclipses and meteorite impacts (Masse 1995; Masse 2007; Masse \& Espenak 2006; Masse et al. 2007). A similar situation existed for Earthly geological events and processes. Thus the sky and the Earth were viewed as being occupied by real sentient beings that were other than pure human. In addition, certain sporadic natural events (such as the recurrence interval of volcanic eruptions) were viewed as divine or supernatural behaviours expected to recur in the future. We will return to these themes later in this paper.

The third aspect of traditional culture and knowledge systems was that the fact of being human was at times stressful and full of fearful events and consequences. Far from being a 'Garden of Eden', the world was periodically subjected to floods, earthquakes, droughts, volcanic eruptions, disease, pestilence, cosmic impacts, and other powerful natural events. Cultural groups had a collective memory of such events and other processes reaching back in time hundreds and even thousands of years. This is evidenced, for instance, by the fact that a surprising number of different cultures seemingly recognized precession, the slow predictable apparent movement of the fixed celestial heavens (particularly the zodiac) due to the tilt of the Earth's axis, a process lasting nearly 26000 years for a complete sequence through the zodiacal constellations. Partly in order to buffer such stress and fear, an attempt was made by traditional cultures to systematically organize their natural and social world into harmonious cosmological packages, which were in turn reinforced by ritual observances and performances. The fixed celestial heavens and common geological processes became a part of these cosmological packages.

And this brings us back to our attempt to provide a satisfactory and straightforward definition for myth concerning our exploration of the relationship between myth and geology. A possible definition especially for those myths occurring as part of the religious cosmological and cosmogonic core of a given traditional culture is the following:

Myth is a structured narrative, in general derived from oral transmission, and typically created or assembled and perpetuated by knowledge specialists who use supernatural elements and images in order to categorize and explain observed natural phenomena and events that are of perceived vital importance or of special relevance to the social order and well-being of a given culture

Having stated our definition of myth, we do not wish to demean the value and insights of the many other theories of myth. Although we choose to emphasize the natural roots of myth, myth does not lack ritual aspects, psychological content, dichotomous or binary-opposite structural rules, 
historical bias, or literary value. It has all of these and more, as should be evident from the various studies contained in the present volume.

\section{The cognitive structure of myth}

To understand how certain myths can carry information about natural events and how to work with that information, one needs to understand certain principles about how myths develop (see Barber $\&$ Barber 2005 for a much fuller account). These principles, originally collected empirically over many years, are closely connected to what cognitive scientists and linguists now know about how the human brain handles language, raw data, memory (including memory failure), and explanation, a junction of cognitive anthropology and anthropological linguistics on the one hand (e.g. D'Andrade 1995; Foley 1997) and cognitive psychology or neuropsychology on the other (e.g. Rubin 1995; Eichenbaum 2002; Ashcraft 2005). Several of our observations regarding the cognitive structure of myth are referred to as 'principles' here and elsewhere (Barber \& Barber 2005); however, the use of this term specifically emphasizes its sense as an empirical deduction. Our use of these principles is meant to enable the reader to visualize aspects of the cognitive structure and diachronic properties of myth. Ultimately, these stated principles will require additional study and validation.

Mythology is a function of the oral transmission of linguistically encoded data. In a non-literate culture, a young person learning an important practical craft like hunting, cooking, weaving, or toolmaking learns it primarily by watching his or her elders and by practising, by visual and kinaesthetic apprenticeship rather than through words. But information about important past events cannot be learned that way. The events must be encoded into language and transmitted entirely by talking and the next generation will then have to remember these tales. Why should they try? Because the information in the stories is important, nay crucial, for the preservation of the group; as crucial as knowing how to make fire or obtain food. After the devastating tsunami of 26 December 2004, in the Indian Ocean, it was reported (CBS News 2005; National Geographic News 2005) that certain tribes in the Andaman Islands survived because of a myth passed down over the generations about 'a wave that eats people'. This wave (actually seven waves according to the story) was said to be brought on by the angry spirits of the ancestors, and could only be avoided by immediately running to high ground if the ocean is observed to recede rapidly.

Consider another type of important information: how to navigate by the stars. The stars are a bunch of more-or-less randomly distributed points of light, so how are you going to remember which is where? We still use the system devised by the old myth-makers: start by dividing the stars into Rorschach-groups. Call this prominent group, say, a hunter (Orion); that one looks like seven sisters (the Pleiades). Fine, now it's easy to remember: the hunter is forever chasing the sisters across the sky! (A story of hunters chasing a bevy of girls is a lot more likely than girls chasing a hunter, so even the direction of movement is encoded memorably.) Add the previously mentioned notion that the sky is a real place populated by sentient beings (deities and demigods) who are capable of 'motion-freezing' and thus immortalizing people and events in the fixed celestial heavens, and likewise throw in notions about the appearance of the Pleiades in relation to agricultural and annual cycles of renewal. Myths are not just 'silly cultural fiction', they are carriers of information once deemed extremely important.

Recovering that original information, however, is not always easy or even possible, for several reasons. The most crippling reason is the 'Silence Principle' (Barber \& Barber 2005, pp. 17-33):

What everyone is expected to know already is not explained in so many words

Myths can't afford to waste precious words on what the members of that culture should already know; so it isn't said. Unfortunately: What is never said may eventually be forgotten entirely.

We can glimpse this process in the writings of Snorri Sturluson, who lived and wrote in Iceland just after it became Christian. Precisely because people were rapidly forgetting the traditional knowledge, Snorri strove to write down the old myths and sagas, sometimes stating explicitly the 'assumed' knowledge that was getting lost. Thus, in telling how Loki, chained to the rocks beneath a venomous serpent as punishment for his misdeeds, would shudder whenever the poison dripped onto his face, Snorri adds: 'You call that an earthquake' (Sturluson 1971, pp. 85-86).

Because of lost assumptions, we cannot hope to reconstruct everything about every myth. But we can help ourselves along by at least recognizing our own unstated assumptions that get in our way. Consider the Klamath Indian story of why the Klamath viewed as lethally dangerous a magnificent lake in their territory, the one we now call Crater Lake, Oregon (see also Vitaliano). According to this tale (written down very soon after Europeans first arrived), the Chief of the Below World got angry at the Klamath tribe and came up to the mouth of his tall mountain, threatening to send the Curse of Fire; whereupon the Chief of the Above World challenged him to battle. 
The former spewed fire, burning ash, and red-hot rocks, followed by a river of fire that came all the way down the mountain. Terrified, the Klamath sent two medicine men who sacrificed themselves by jumping into the great firepit up above. Then the Chief of the Above World pushed the entire top of the mountain in on the Chief of the Below World, whose voice was never heard again and slowly over the eons the hole filled with water (Clark 1953, pp. 53-55).

Geological analysis confirms that there was once a mountain on that spot, and that it erupted violently, spewing around $50 \mathrm{~km}^{3}$ of magma, ash, and lava-bombs until the emptying of its magma chamber caused the caldera walls to collapse inward, forming a pit some 4000 feet deep that later filled with water (Bacon 1983; Klug et al. 2002), just as the myth says. Since the eruption happened almost 7700 years ago (Zdanowicz et al. 1999), this myth must have been carried down for nearly eight millennia.

Our own (typical) assumption, as we read something like the Klamath myth, is that since we do not agree with the Klamath explanation for this fiery occurrence, there is nothing worth looking at scientifically in the story. But one of our problems as modern observers of myth (or even observers of events such as car accidents) is that people tend to present their observations and their assumed explanations all tangled up together. On the other hand, if we strip away the explanations proffered but keep and investigate the observations, we can see that the observations in myths are fairly accurate (as far as they go), and at the very least they alert us to something of geological interest that happened in a particular place. Furthermore, if we take for the moment the Kalamath step of assuming that the Curse of Fire was caused by a wilful being (more of this below), then we can see that the quite logical strategy is to placate that beingwith a gift, bribe, or sacrifice-which is exactly what they did in their attempt to prevent or delay future destructive eruptions. That is, the myth unrolls logically from its own premises-it is not haphazard. In fact, there are many myths concerning geological events in the Pacific Northwest (e.g. Ludwin et al.), where until the nineteenth century the population remained stable, that is unreplaced by cultures that had not witnessed the events and therefore did not know what was referred to.

Paying attention to the reported response can help us ferret out what the underlying explanations and unstated assumptions were, which usually come down to us all tangled up with the observations. From little observational 'snapshots', an entire newsreel is constructed. Everything is set out in terms not of what was observed but of assumed explanations. For example, the normal natural decomposition processes of a corpse in a coffin can become a macabre tale of horror to uninformed observers (Barber \& Barber 2005, pp. 31-33). Barber \& Barber (2005, pp. 30-33) have nicknamed this common myth-making process the 'Movie Construct'. Seriously mismatching courtroom recollections of accidents and crimes show that the impulse to indulge in the Movie Construct is quite as strong with us as with ancient people.

Why are we humans, ancient and modern, so hell-bent on explanation? Cognitive scientists have a lot to say about that; what matters to us here is that we do demand explanation of some sort, and if we can't stockpile enough data to figure out the true cause and effect we turn elsewhere. In particular, we explain things by saying, 'It's this way because it's like $X$ '. In mythology, this can be stated as the 'Analogy Principle' (Barber \& Barber 2005, pp. 34-40):

If any entities or phenomena bear some resemblance in any aspect, they must be related

So if I like to hurt those who have hurt me, then probably the Chief of the Below World does too, that's why he is sending the Curse of Fire. And if, when I'm angry, I might relent if the offender gives me a major present, then, by analogy, the Chief of the Below World may relent if offered the greatest of sacrifices. Analogical reasoning is everywhere in mythology, but it gets tangled up with another problem that we must investigate before we can proceed.

Most of the time we navigate through life by probability rather than by logic. We become habituated to routine behaviour and develop routine expectations. Our brains accumulate a lot of practical observations, and when something new happens, we look for the closest match in our data rather than assess the logic of the situation (which takes us much longer).

This type of reasoning can lead to deadly consequences. In the case of the 2004 Indian Ocean tsunami, it is likely that some coastal villagers who were used to the subsistence gleaning of reefs at extreme low tide, saw the (much too rapidly) exposed bare reef as an opportunity to collect stranded fish rather than as a signal to immediately run to high ground. Such an unfortunate response has been reported elsewhere in similar circumstances. For example, hundreds of Hawaiians flocked to various exposed reefs immediately prior to a tsunami event in 1837 , dozens of whom drowned in those locations where the heights of runnup were greatest (Jarves 1843, pp. 20-22). Interestingly, many other Hawaiians were observed to be greatly alarmed at the initial receding waters and sought the shelter of higher ground, perhaps mirroring the self-preserving 
behaviour of those Andaman tribes in December 2004 who were influenced by their oral traditions.

An implication and its reverse are not automatically equivalent. In mythology, as in practical life, we often behave as if they were and apply rather liberally what logicians call the Fallacy of Affirming the Consequent. In the above example, we know that if $(P)$ when it is the farthest ebb of a spring tide, then $(Q)$ fish and other subsistence items will be exposed on the reef. But it doesn't follow that if there are fish exposed on the reef $(Q)$, it's due to the ebb of a spring tide $(P)$.

Perhaps the furthest-reaching application of this fallacy for mythology is what has been called the Wilfulness Principle (Barber \& Barber 2005, pp. 41-52):

Humans will things to happen, then set about to make them happen. Therefore, if something happens, it must have been willed

If hot rocks fly out of a mountain, someone must be lobbing them. If the Nile suddenly rises each summer, it must have chosen to do so. If a tree falls over, or a house or a mountain falls down, or if islands suddenly appear or disappear (Nunn \& Pastorizo) someone must have pushed or pulled it. (Surely this is an easier hypothesis than our modern one concerning gravity) Our literate modern world permits the massive storage of knowledge that both allows us to overcome wilfulness as an explanation for natural phenomena, but also blinds us to the logic of those wilful explanations that are present in myth.

The Wilfulness Principle provides a rationale for spirits and deities, often invisible, who can be anywhere and do anything, and can provide explanations for practically everything. Thus we get fantastic animals and associated place names, such as the earthquake-related Fenris wolf and his abodes in Nordic tradition (Morner); the eruptive products of Hawaiian volcano demigoddess Pele and her large supernatural family (Easton 2004); historical figures transformed to supernatural heroes such as the role of Ali, son-in-law of the Prophet Mohammad in creating and destroying the travertine dams and lakes of Afghanistan (Bourrouilh-Le Jan et al.); or even the 'sweat' of the Argonauts staining the rocks of Elba Island (Dini et al.).

This Wilfulness Principle, in turn, is subject to what has been termed the Kinship Principle (Barber \& Barber 2005, pp. 44-49):

Since family members typically resemble each other, phenomena that resemble each other must be kin

The Sun and Moon are often viewed as (wilful) siblings, as are the winds, while the volcanoes of the Pacific Northwest are typically viewed either as siblings or as the Sky Spirit's various wives-who throw rocks at each other when they become jealous, just as human rivals might.

And now we come to another major hurdle for modern thinkers. We expect one explanation for something, but mythical thinking celebrates the Multiple Aspects Principle (Barber \& Barber 2005, pp. 53-70):

A phenomenon may be explained mythically as many times as it has 'significantly' different (analogizable) aspects

Thus we view it as 'inconsistent' that the ancient Greeks or Egyptians should have had several different sun gods. We see one sun, so we expect one god. But the sun has many important aspects, each of which affects us differently. Thus Greek Helios (like Egyptian Aten) refers to the round disk of the sun that shines fiercely above you; but Greek Hyperion (literally 'going over') encapsulates the sun crossing the sky each day (Fig. 1); Eos and Hesperus represent the sun respectively in its crucial aspects of coming up in the morning (creating the day) and going down in the evening (cutting off the day); whereas Apollo, that vibrant and handsome youth, represents the sun's lifegiving properties (among other things).

With so many aspects of 'single' phenomena represented in a culture's mythology, we must cultivate the habit of moving our mental cameras around to as many viewpoints as we can find, so as to help solve what is called the Camera Angle Problem (Barber \& Barber 2005, pp. 56-59):

To understand what a story is talking about, we may have to observe the situation from a very particular viewpoint.

Multiplicity of aspects can come from another source, however, than simply the variety of possible analogies that one person or culture can come up with. We must also recognize that the same event may end up being viewed from different camera angles by different groups of people for geographical reasons. For instance, during a major volcanic eruption, people engulfed some distance away by the volcano's ash cloud will have very different experiences to encode into myth than the people swamped by flows of lava or mud, let alone than those people who saw only its glow from afar. Thus the $c .1625$ BC catastrophic eruption of Thera in the Aegean generated such wildly different myths among the surrounding peoples that it takes a 'zonal analysis' (see also Masse \& Masse), based on modern geological findings, to puzzle the pieces back together to see that they all record (different aspects of) the same event (Barber \& Barber 2005, pp. 75-87). Thus the myths from Egypt record in scattered form the ash cloud, distant glow, and tsunami; those from the Greek mainland, nearby but fortunately upwind, record as a divine battle the tremendous heat, ear-splitting 


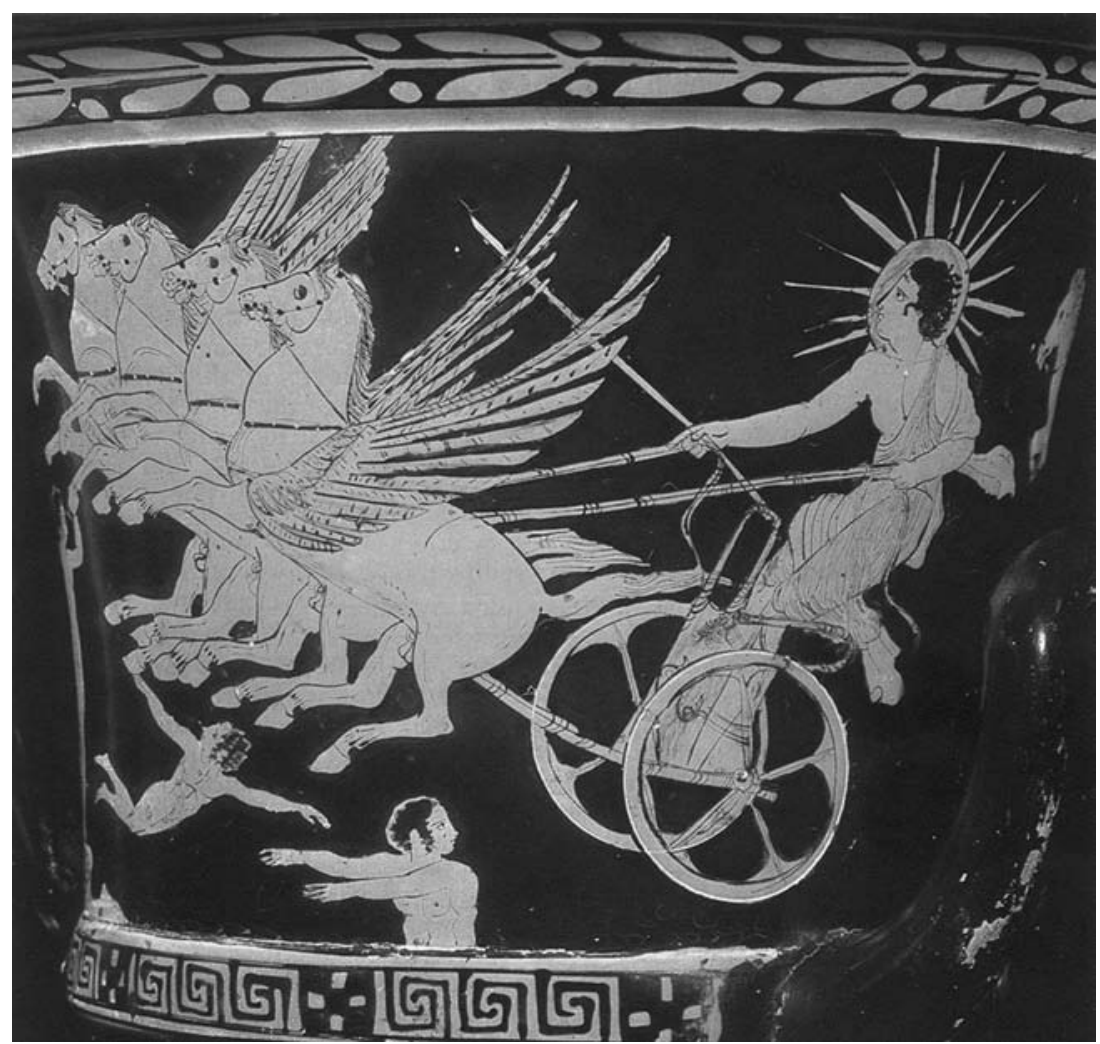

Fig. 1. The god of the Sun, Helios (Hyperion), driving his chariot across the sky. Greek krater dated 435 BC. [Courtesy of the British Museum.]

noise, and flying ejecta, as well as the tsunami; and the myths from the Hittites in central Turkey sing of a bellowing young giant standing in the sea and growing up rapidly until it challenged the sky god himself-a wonderful image of the towering column of ejecta as seen from afar and, taken as wilful!

Not only are there different physical perspectives of a single event, but those affected by a natural catastrophe typically expend a great amount of effort in trying to survive. They will not feel exactly the same physical sensory experiences as other victims, but certain experiences will be remembered more clearly and others not. Had Pliny the Elder somehow managed to survive the AD 79 eruption of Mt Vesuvius, his story may well have emphasized different aspects of the eruptive phenomena from that of his nephew, Pliny the Younger, who witnessed the event from a safe distance. Blong (1982) in his exquisite analysis of the myths associated with the seventeenth century Long Island plinian eruption off the coast of Papua New Guinea, not only documented significant differences in myth storyline due to geographic location, but also discovered that no one cultural group had myths containing all of the elements of the eruption. It was only by looking at the myths from all of the widely distributed cultural groups that he was able to get the best composite picture of the overall eruption.

There are other problems, however, in trying to interpret the origin of a myth, problems that arise because of changes that inevitably occur as myths are told and retold. Because the human memorychannel is restricted, information regularly gets compressed, and may do so in ways that obscure certain facts. One of the principal mechanisms of compression is what is referred to as the Principle of Attraction (Barber \& Barber 2005, pp. 113-117):

Once the stories around something/someone achieve sufficient mass, that thing/person attracts yet other stories, via any 'significant' point of resemblance

Points of attraction include the same type of event, same place, or same name. Thus, in the Bible, all Egyptian pharaohs end up rolled into what appears to be one person, 'Pharaoh'. (This makes it hard, of course, to know under whose reign an 
event happened. The point of attraction is the name.) In Greece, if something happened that must have required prodigious strength, such as a river changing course suddenly, it must have been done by that strong-man, Heracles (point of attraction: a quality), or if it occured in Athens, it must have been done by Theseus (point of attraction: place).

Another parameter that gets compressed is time, expressed in the Perspective Principle (Barber \& Barber 2005, pp. 117-120):

As we get further from an event, our perspective gets flatter, and we can no longer distinguish earlier from later events so easily. It's all 'back then' some time

For example, we ourselves can easily see that Abraham Lincoln preceded John F. Kennedy by a century; but we have a much harder time if we jump back a couple of millennia and ask who came first, Pliny or Vergil, two famous people also separated by a century. Or try Cheops and Sargon, back another 2500 years. Thus, the Exodus now seems to be a compression of several trips from Egypt back to Palestine, spread out over perhaps as much as 800 years and rendered as a single account (written down several centuries after the last of these, when all sense of their separateness in time had been lost; Barber \& Barber 2005, pp. 86, 91-92; Assmann 1997).

Various other things happen to myths as they pass down through the oral pipeline. But the principles presented here should be sufficient to show the reader that myths are not hopelessly 'off the wall', but that with care one can begin to use them as a guide to interesting past events, particularly in the realm of geology and astronomy. For as long as the tellers of these myths could look up and see direct reminders of the events-actual volcanoes, stars, bodies of water, and the likethey had continuous anchors to reality as well as prompts reminding them to keep telling the tale.

\section{Conservation in the traditional oral transmission of myth}

Jan Vansina (1985) has eloquently argued that oral history (the oral transmission of historical information) is a valid and extremely rich type of history. While recognizing several of the problems discussed in the previous section, he also notes that orally transmitted history is structured and is amenable to analysis. Vansina (1985, pp. 188-189) explicitly recognizes the potential value of geology and astronomy to serve as a chronological anchor, although based on twentieth century attempts to apply these two disciplines, he suggests that 'absolute dating will not be as easily achieved as once believed'. Vansina (e.g. 1985, pp. 166-167) also shows some ambivalence towards myth as a faithful vehicle for transmitted oral history.

We suggest that there are several 'conservation principles' (once again emphasizing these as empirical deductions for eventual validation) that influence and actually help to enhance the accuracy of the oral transmission of myth down through successive human generations despite the perturbing influences noted in the previous section. Polynesia, particularly traditional Hawaiian culture, provides a unique and exquisitely historical model of myth transmission that illuminates the conservation processes perhaps better than that observed for any other past complex society (Masse 1995; Masse et al. 2007). In Hawaii, myths and legends were typically attached to royal chiefly genealogies; that is, actual specific mythic events were described as having taken place during the reigns of specific chiefs whose names appear in royal genealogies. Some Hawaiian genealogies extend back in time more than 95 generations prior to King Kamehameha in the late eighteenth century. Evidently, such genealogically-situated oral records of events were a common practice among many complex societies, often being eventually transcribed into written texts. For example, we see fragments of such oral records in Nahuatl and Mixtec codices in Mexico, in ancient Mesopotamian king lists, in Hesiod's Theogony, in the third century $\mathrm{BC}$ 'Bamboo Annals' of China, and in the annals of fourth century BC Egyptian priest and historian, Manetho (see also Masse 1998). But for various reasons that will become evident below, Hawaii has a much better preserved record of orallytransmitted myths and their linkages to genealogies than is the case elsewhere in the world.

That Hawaiian myths encode dateable natural events was first demonstrated through the analysis of a series of myths relating to the volcano goddess Pele (see also Vitaliano 1973, this volume). In these myths, specific named and historically known lava flows were described as having been formed by Pele during 'battles' with demigods that were linked to the reigns of chiefs appearing in the genealogies, or in some cases, the battles were between Pele and the genealogical chiefs themselves. An analysis of radiocarbon dates of burned vegetation associated with these named lava flows, collected by scientists from Hawaii Volcanoes Observatory (e.g. Holcomb 1987), indicated a close match with dates assigned to the genealogies when the length of an average 'royal chiefly generation', that is the birth of a royal chief to the birth of his or her first-born heir, was estimated at between approximately 20 to 25 years (Masse et al. 1991). There are at least eight such matches between radiocarbon-dated eruptions and genealogical chiefs, with the earliest mythicised eruptions occurring 
42 generations (c. 880 years) prior to Kamehameha (Masse et al. 2007). A ninth possible match remarkably even suggests the witnessed observation of a major eruption in the young Kilauea caldera in the seventh century $\mathrm{AD}$, roughly coincident with the presumed initial Polynesian colonization of the island chain.

In perusing Hawaiian mythology more closely (Masse 1995; Masse et al. 2007), it could be demonstrated that a remarkable number of known (from Asian, European, and Middle Eastern records) or reconstructible historic transient celestial and meteorological events were detailed in the storylines of myths attached to the genealogies. These included a sizeable number of unusual comets (including the coincidence of the AD 1301 apparition of Comet Halley with a massive Kilauea Volcano flank eruption), periods of great meteor storms, an auroral substorm, and at least five Hawaiian total solar eclipses (AD 975, 1104, $1257,1480,1679)$ whose paths and characteristics were reconstructed by astronomer Fred Espenak of NASA Goddard (Masse et al. 2007). The unique characteristics of a sunset Samoan total solar eclipse in AD 761 has been determined as the basis for a set of famous Polynesian myths about the demigod chief Mauiakalana (an early chief in the royal Hawaiian genealogies) who snared the Sun and held it still so that his mother would have more time to dry her tapa barkcloth (Masse et al. 2007). Another solar eclipse in $\mathrm{AD}$ 605 may have been witnessed in the Tuamotua archipelago by ancestral Hawaiians prior to their colonization of Hawaii.

Thus we have a relatively-ordered genealogical, and in some cases absolutely dated, chronology of orally-transmitted myths of observed natural events in Hawaii (and earlier ancestral island groups) stretching back in time more than a thousand years. Because of the multiple cases of exact matches between specific myths and historic natural events, we know when these myths were created, with whom they were associated, and many details regarding the principles of their construction and how the myths were used in Hawaiian culture (e.g. religion, cosmology, myth performance, astrological prognostication, chiefly reification and power). These are even competing storylines of the same witnessed natural event created by different social groups on different islands in the Hawaiian archipelago, which give a sense of how different observers fashioned their stories.

In Hawaii, major transient celestial and meteorological events, along with volcanic eruptions and tsunami, were both the persona and property of the royal chiefs, serving as mana, a powerful supernatural force believed to dwell in a person or object.
When a royal chief of proper lineage was initially conceived, priests spent the next several months scanning the skies (and the Earth) for various 'signs of royalty' (Masse et al. 2007). A similar natural event encoding practice was conducted around the time of circumcision (subincision) rites for the children of royal chiefs. When signs such as a comet, meteor shower, or rainbow were found, priest specialists created stories about these signs, occasionally in the form of procreational exploits ('genital chants'), which then became forever euhemeristically identified with the chief. The more spectacular the royal sign (or royal signs in the case of multiple co-occurring natural events), the more extravagant and filled with supernatural overtone the story became, and the greater mana was bestowed upon the newborn or newly circumcised royal chief. Several of the most spectacular natural events even became embedded in royal genealogical chants, such as the 2102-line Kumulipo genealogy which was chanted to Captain James Cook at the Makahiki New Year's festival in December 1778, when Cook was thought to be an incarnation of the Hawaiian god Lono (Liliuokalani 1978; Beckwith 1972; Johnson 1981).

These observations regarding Hawaiian/Polynesian myth (Masse 1995; Masse et al. 2007) suggest four conservation 'principles' pertaining to the preservation of information content in the oral transmission of myths encoding natural events. The first can be termed the 'Snapshot Principle':

Sometimes myth storylines are created during or immediately after the observation of a major natural event

This observation belies the long-held assumption, stemming at least back to Euhemeros, that myths are formulated long after the events in question (generation and perhaps centuries), and that the true facts of a story are eventually forgotten, transforming into a supernatural myth. The Hawaiian data instead indicate that myths are a naked-eye snapshot of a natural event, and that the supernatural images are present from the very beginning. The supernatural character of the story simply represents an attempt at explanation by holistic cultures who believe that the sky and Earth are inhabited by sentient beings (e.g. gods and demigods) that are not human, as noted earlier for the Wilfulness Principle. This principle does not exclude the possibility that some of the distorting mechanisms noted in the previous section may impact a myth storyline.

The analogical character and snapshot construction of Hawaiian myth from natural events is evident in a legend that describes a total solar eclipse in 1679, less than 100 years before Captain James Cook first landed in Hawaii. 
Briefly told, the legend is about a poor commoner, Kapo'i (ka-po-i, the great darkness), on Oahu Island, who being hungry, discovered some owl eggs in the grass. He was about to cook them when a large owl appeared in his window. The owl begged for the lives of his children, and Kapo'i, feeling sorry for the owl, gave the eggs back. The grateful owl told Kapo'i to build a small temple to honour the owl, which would ensure that good fortune would follow him. Kapo'i builds the temple. Unfortunately, this was at a time when the King of Oahu Island (Kakuhihewa, who appears in the royal genealogy of Oahu Island), had prohibited anyone from building shrines and temples except for himself. Kapo'i was seized and placed in the custody of the priest of Kakuhihewa's temple at Waikiki Beach, and was told that he would be sacrificed at sunrise the following morning so as to help dedicate Kakuhihewa's temple. The next morning, immediately prior to the execution and as the first rays of the sun begin to hit the ground, several huge bands of supernatural owls flew out of the mountains and began to attack Kakuhihewa's priests and cover the rising Sun so that its light was extinguished. A fearful Kakuhihewa released Kapo'i, the owls disappeared and the sunlight returned, and Kapo'i became an honoured and respected lesser chief.

The rich details of this myth unquestionably capture to an extraordinary degree the details of the observed natural event that took place. A total solar eclipse, whose path was centred on Waikiki Beach, took place at sunrise on 10 April 1679. This coincides in genealogical time when Kakuhihewa was an aged chief (other stories indicate that he may have ruled more than 50 years). The April date also coincides with the season during which indigenous Hawaiian owls (pueo) are most likely to lay eggs. As for Kapo'i himself, there is no indication whether he was a real person with an extraordinary bit of good fortune, or instead was the symbolic manifestation of the divine forces responsible for the eclipse (as suggested by his literal name). We suspect the latter.

The second oral transmission conservation technique can be referred to as the Expertise Principle, particularly as applied to myths forming the religious cosmology and cosmogony of a given culture:

Myths were likely created and perpetuated by highly trained and gifted experts.

Hawaiian royal storytellers were not casual artists. They were extremely knowledgeable priests who were born into the role and trained to read auguries and to tell stories that extolled the virtues and mana of their chiefs. Some of these stories, particularly genealogical chants, could be hundreds or even thousands of stanzas in length, and would take many hours or days to tell in their entirety. Because of the implications for royal lineages and the chiefly reification process, the accurate transmission of oral history was not only highly valued but was mandatory, and priests who did their job 'poorly' were liable to be put to death. Other complex societies had similar institutional levels of expectation, and even less complex societies used and enforced mechanisms to ensure that the transmission of myths, particularly sacred creation and cosmogonic stories, were entrusted to welltrained and gifted individuals.

Bentor (1989) describes an example of how geological events, in particular catastrophic ones, became eventually encoded in the Bible as chronological markers. The time of the beginning of the teachings of prophet Amos, for instance, is 'two years before the earthquake' (Amos, 1:1). Archaeological evidence of this earthquake was found after excavation the city of Hazor, in Galilee, providing a date of around $760 \mathrm{BC}$. The earthquake was still remembered at the end of fourth century $\mathrm{BC}, 450$ years later (Zechariah 14:5).

The third oral transmission conservation technique of myth transmission is referred to as the Performance Principle:

The oral transmission of myth was not simply spoken but was 'performance driven'; that is, myth storylines were systematically acted out in rituals using a wide variety of reinforcing media and mnemonic devices

Stories commemorating the royal birth signs for Hawaiian chiefs were created, rehearsed, and staged several times prior to the actual birth or circumcision of the chief. Sections of the story were put into song or chant, and at least some of the story was performed as a hula dance, seemingly re-enacting aspects of the observed characteristics of the natural event, such as the behaviour of rocks and lava during Pele's battles or the manner in which a comet transited through the fixed celestial heavens. These birth event stories would continue to be periodically performed during the life of the chief, and those embedded in royal chief genealogies would be performed once or more a year for as long as the lineage was in existence. Some stories were performed at specific times of the year, matching the annual timing of the original natural event, or within the context of important seasonal festivals such as the New Year or summer and winter solstice.

The fourth and final conservation technique of myth transmission noted here can be termed the Redundancy Principle:

Key aspects of a myth storyline are often repeated so as reinforce the importance of that portion of the story and the ability of the audience to remember it 
This principle should be obvious and does not require much in the way of explanation. However, such redundancy greatly annoyed nineteenth and early twentieth century folklorists who often resorted to streamlining or otherwise retelling myths in order to make them acceptable to their perceptions of literary tastes, as exemplified by the following note to a compendium of New Zealand Maori myths (Izett 1904, p. iv-v):

It will be discovered at a glance that in this work the language of the translators has been thrown wholly aside, and any supposed obligation to adhere to the Maori form of arrangement has not been recognised. It has been sought to preserve the spirit and the detail of each legend whilst robing them in entirely new garments .... Conversations have been extended or introduced such as, under the circumstances of each situation, might naturally be expected to have taken place; here and there little bits of description have been ventured.

Of course the problem with such modern retelling is that original storyline details become mixed in sequence, embellished, made fictional, or lost entirely. This technique greatly reduces our ability to understand and reconstruct the natural event(s) being portrayed in a given myth.

Having outlined these principles, a final question and challenge for future researchers must be raised. Is the model of conservation principles presented here, largely derived as it is from insights into Hawaiian and Polynesian myth, applicable across the world?

The answer to this question is both a qualified 'yes' and 'no'. Yes, because these principles seem to apply to myth in many areas with cultural groups of greatly differing social complexity but also with strict religious codes of how cosmological oral history and sacred mythology is transmitted, for example Native Americans (both North and South America), Australian Aborigines, and many SE Asian societies.

The 'no' stems from the fact that there are multiple transmission methods by which myth can be perpetuated through the generations. Operating simultaneously with sacred myth transmitted by priests and shamans using the conservation principles outlined above are myths for which the context of transmission is family-based or popular in nature. Eugenia Shanklin provides an excellent example of such kin-based and popular myth in her discussion of the Lake Nyos catastrophe. The problem with the historical content of such myth is that it has not been rigorously subjected to the strictures of the conservation principles and therefore may be less likely to reflect the reality of the original observed natural phenomena.

We suggest that anthropologists, folklorists, and other students of myth have not carefully examined this problem and may mix these distinct genera of transmitted myths. Also, particularly in the case of ancient myths, it is often difficult to know for certain what myths may have been created by individuals who were neither knowledge specialists nor gifted observers. These situations may be at least partially responsible for the failure by western science to understand better the historical observational foundation of myth. The topics of multiple systems of myth transmission and the skills of the original mythmaker are potentially critical for any and all attempts to derive historical information from myth storylines and deserve additional future scrutiny. Detailed contextual analyses of the myths themselves may yield important clues for how they should best be categorized and studied.

\section{The future of myth in science}

Whether myth has a future depends on its capacity to meet the challenge posed by modern science .... Modern challenges to myth have been made on intellectual, theological; and political grounds .... The chief modern challenge, however, has come from natural science, which does so well what myth had long been assumed to do: explain the origin and operation of the physical world .... To accept the scientific explanation of the world is to render the mythic one both superfluous and outright falsesuperfluous because superseded by the scientific account, false because incompatible with the scientific one (Segal 1996, p. 82).

Fortunately, it is not necessary to make the sobering and difficult choices outlined in the essay by Robert Segal, to ensure the survival of myth in our modern scientific world. It should be evident from this book that myth is neither superfluous nor false. Rather, myth presents us with the surprising opportunity to extract from the historical cultural record of many regions an unprecedented view of the impact of geological and solar system process and events during the past several thousand years.

The process of extracting from myth such records of natural events and processes in most cases will not be easy. It will require the application of a number of geological, astronomical, and archaeological tools, as well as those from the cognitive sciences, history, and the humanities. We still have much to learn about the theory and methods of our nascent discipline of geomythology. Not all myths are amenable to such analysis, and fewer still provide the details necessary to identify actual geological processes much less specific datable events such as major earthquakes, volcanic eruptions, floods, and cosmic impacts. However, it is certain these defined events provide us with the opportunity to understand local geological histories and the actual risks posed by certain types of natural phenomena.

We should not downplay the fact that myths also shed light on aspects of cognition, and the historical, social, and literary context of cultural evolution and human thought. We are not about to claim that 
just because most modern scholars have somehow missed the possible natural history core of myth that their own studies and insights are cheapened or otherwise diminished by such oversight.

On the other hand, we would gently suggest that if there is a historical kernel to many or most traditional/ancient myths, then this may warrant some new ways of thinking about the sociology of myth. Indeed, if myth somehow provided a competitive advantage for certain cultural groups to continue their existence in contradistinction to other groups, whether or not due to psychological advantage (e.g. stress reduction), the advantages of increasing social complexity fostered by mythic thought, or the advantages of real information on natural risks being contained in the myths, this might be construed as a socio-biological dimension deserving of further study. We do not necessarily subscribe to such a purely socio-biological viewpoint for myth, but find it an interesting topic worthy of further scrutiny.

We cannot overemphasize the likelihood that geomythology can contribute to a better understanding of geophysical hazards and risks for specific regions, enhance our knowledge regarding present uncertainties in modelled geophysical processes, and potentially can facilitate improved efforts at risk reduction. One example in this volume is the work by Bryant et al. on potential tsunami effects associated with oceanic cosmic impact (see also Bobrowsky \& Rickman 2007; Masse \& Masse). In respect to risk, we need systematically to develop databases to aid in our identification and analysis of geophysical information in historic texts and oral traditions, such as that being implemented for the Mediterranean area by Vittori et al. The geomythological study of risk should not only focus on the myths themselves but also on a systematic reappraisal of the complete set of images contextually associated with past cultures. The work performed by Hough in looking at Native American archaeological rock art in relation to California earthquakes exemplifies such an approach.

And finally, we agree with Lanza \& Negrete that myth can serve as both a model and a marvellous narrative tool for educating the lay public about geology and our place in the natural world. Such education can range from the increased careful use of myth, where appropriate, as an adjunct to the public interpretation of geological parks and formations (as noted by Motta \& Motta and by Mayor), to video documentaries and other creative interpolations that blend myth and the visual arts.

The case studies in this book are but a small sample of the myths that can be studied through the techniques of geomythology. Like the proverbial tip of the iceberg, much useful natural history information is undoubtedly lurking in the large body of as yet unanalysed world myths. Such study should complement and add to our understanding of Earth process and Earth history. At the very least, our various geomythology researches provide us with a profound respect and appreciation for the observational powers of our ancestors, and help to demystify the mythological past.

We thank the organizing committee of the 32nd International Geological Congress for the opportunity to conduct the Myth \& Geology symposium at the Florence meetings in 2004; the volume authors for their excellent contributions and patience during the editorial process the volume paper reviewers for the general excellence of their suggestions for paper improvements; and Angharad Hills and John Gregory of the Geological Society of London for their enthusiastic support of this volume. All of these individuals were an inspiration in preparing this introductory chapter. We particularly thank our own paper reviewers, D. E. Doyel, F. McCoy, and G. Schrempp for comments that considerably strengthened this chapter. McCoy was also a source of stimulating discussions with the Barbers in the preparation of their 2005 book. It is with a sense of eager anticipation that we look forward to a forthcoming period of vigorous growth in the nascent discipline of geomythology.

\section{References}

AshCraft, M. H. 2005. Cognition (4th edn). Prentice Hall, NJ.

Assmann, J. 1997. Ancient Egyptian antijudaism: a case of distorted memory. In: SCHACTER, D. (ed.) Memory Distortion. Harvard University Press, Cambridge, 365-376.

BACON, C. R. 1983. Eruptive history of Mount Mazama and Crater Lake Caldera, Cascade Range, U.S.A. Journal of Volcanology and Geothermal Research, 18, 57-115.

BAlter, M. 2004. The Goddess and the Bull: Catalhöyük, an Archaeological Journey to the Dawn of Civilization. Simon \& Schuster, New York.

BARBER, E. W. \& BARBER, P. T. 2005. When they Severed Earth from Sky: How the Human Mind Shapes Myth. Princeton University Press, Princeton.

BASCOM, W. 1965. The forms of folklore: prose narratives. Journal of American Folklore, 78, 3-20.

BecKwith, M. W. 1972 (orig. 1951). The Kumulipo: A Hawaiian Creation Chant. University of Hawaii Press, Honolulu.

Bentor, Y. K. 1989. Geological events in the Bible. Terra Nova, 1, 326-338.

Blong, R. J. 1982. The Time of Darkness: Local Legends and Volcanic Reality in Papua New Guinea. University of Washington Press, Seattle.

Bobrowsky, P. \& Rickman, H. (eds) 2007. Comet/ Asteroid Impacts and Human Society. SpringerVerlag, London.

BRISSON, L. 1998. Plato the Myth Maker. University of Chicago Press, Chicago. 
Campbell, J. 1989. An Open Life: Joseph Campbell in Conversation with Michael Toms. Harper \& Row, New York.

CASKey, J. L. \& BlackBurn, E. T. 1997. Lerna in the Argolid: A Short Guide, revised edition. Lerna Publications Committee, American School of Classical Studies at Athens.

CBS News. 2005. Sea Gypsies see signs in the waves. (March 20, 2005). Http://www.cbsnews.com/ stories/2005/03/18/60minutes/printable 681558.shtml.

Clark, E. 1953. Indian Legends of the Pacific Northwest. University of California Press, Berkeley.

D'Andrade, R. G. 1995. The Development of Cognitive Anthropology. Cambridge University Press, Cambridge.

De Boer, J. Z. \& Hale, J. R. 2000. The geological origins of the oracle at Delphi, Greece. In: McGuire, W. J., Griffiths, D. R., Hancock, P. L. \& Stewart, I. S. The Archaeology of Geological Catastrophes. Geological Society, London, Special Publications 171, 399-412.

De Boer, J. Z., Hale, J. R. \& Chanton, J. 2001. New evidence of the geological origins of the ancient Delphic oracle (Greece). Geology, 29, 707-710.

Deloria, V., JR. 1995. Red Earth-White Lies: Native Americans and the Myth of Scientific Fact. Scribner, New York.

Dorson, R. M. 1955. The eclipse of solar mythology. Journal of American Folklore, 68, 393-416.

Doty, W. G. 2000. Mythography: The Study of Myth and Rituals (2nd edn). University of Alabama Press, Tuscaloosa.

Dundes, A. (ed.) 1984. Sacred Narrative: Readings in the Theory of Myth. University of California Press, Berkeley.

EAston, M. G. 2004. Hawaiian volcano mythology: provenance and evolution. Paper 183-5 presented at the 32nd International Geological Congress, Florence, Italy.

Eichenbaum, H. 2002. The Cognitive Neuroscience of Memory: An Introduction. Oxford University Press, Oxford.

Feldman, B. \& Richardson, R. D., JR. 2000 (orig. 1972). The Rise of Modern Mythology: 16801860. University of Indiana Press, Bloomington.

Foley, W. A. 1997. Anthropological Linguistics: An Introduction. Blackwell, Oxford.

FontanelLe, B. 2000 (orig, 1724). Of the origin of fables. In: FELdMAN, B. \& RichaRdSON, JR., R. D., (eds) The Rise of Modern Mythology: 1680-1860. Indiana University Press, Bloomington, 7-18.

Friedrich, W. L., Kromer, B., Friedrich, M., Heinemeier, J., Pfeiffer, T. \& Talamo, S. 2006. Santorini eruption radiocarbon dated to $1627-1600$ B.C. Science, 312, 548.

Goodison, L. \& Morris, C. 1998. Ancient Goddesses. British Museum Press, London.

Graf, F. 1993. Greek Mythology: An Introduction (trans by MARIER, T.). Johns Hopkins University Press, Baltimore.
Greenberg, J. K. 2005. The Hebrew scriptures and geology. Manuscript in the author's possession. Department of Geology, Wheaton College, Illinois.

Guidoboni, E. (ed.) 1989. I terremoti prima del Mille in Italia e nell'area mediterranea. ING-SGA, Bologna.

Haviland, W. A. 1975. Cultural Anthropology. Holt, Rhinehart \& Winston, New York.

Hodder, I. 2006. Çatalhöyük: The Leopard's Tale, Revealing the Mysteries of Turkey's Ancient 'Town'. Thames \& Hudson, New York.

Holcomb, R. T. 1987. Eruptive history and long-term behavior of Kilauea volcano. In: DECKER, R. W., Wright, T. L. \& Stauffer, P. H. (eds) Volcanism in Hawaii, Vol 1. US Geological Survey Professional Paper 1350, 261-350.

Honko, L. 1984 (orig. 1972). The problem of defining myth. In: Dundes, A. (ed.) 1984. Sacred Narrative: Readings in the Theory of Myth. University of California Press, Berkeley, 41-61.

IzetT, J. 1904. Maori Lore: The Traditions of the Maori People, with the More Important of Their Legends, Compiled for the Government of New Zealand. Renaissance Books, Dunedin, New Zealand.

JARVES, J. J. 1843. History of the Hawaiian or Sandwich Islands. Tappan \& Dennet, Boston.

Johnson, R. K. 1981. Kumulipo: Hawaiian Hymn of Creation (Vol. I). Topgallant Publishing, Honolulu.

Jung, C. G. \& KeRÉnyI, C. 1993 (orig. 1949). Essays on a Science of Mythology: The Myth of the Divine Child and the Mysteries of Eleusis. Princeton University Press, Princeton.

KerÉnYI, C. 1993 (orig. 1949). Prolegomena. In: JunG, C. G. \& KeRÉNYI, C. Essays on a Science of Mythology: The Myth of the Divine Child and the Mysteries of Eleusis. Princeton University Press, Princeton, 1-24.

KIRK, G. S. 1974. The Nature of Greek Myths. Penguin, London.

Klug, C., Cashman, K. V. \& Bacan, C. R. 2002. Structure and physical characteristics of pumice from the climactic eruption of Mount Mazama (Crater Lake), Oregon. Bulletin of Volanology, 64, 486-501.

LEgGe, J. 1994 (orig. 1872). The Chinese Classics, vol. III, The Shoo King. SMC Publishing, Taipei, Taiwan.

LÉVI-Strauss, C. 1969. The Raw and the Cooked: Introduction to a Science of Mythology (Vol. I). Harper \& Row, New York.

LiLiUOKALANI 1978 (orig. 1897). The Kumulipo: An Hawaiian Creation Myth. Pueo Press, Kentfield, CA.

Lincoln, B. 1999. Theorizing Myth: Narrative, Ideology \& Scholarship. University of Chicago Press, Chicago.

Lowe, M. \& Shaughnessy, E. L. (eds) 1999. The Cambridge History of Ancient China, from the Origins of Civilization to 221 BC. Cambridge University Press, Cambridge.

Ludwin, R. S., Dennis, R. ET AL. 2005. Dating the 1700 Cascadia earthquake; Great coastal 
earthquakes in Native Stories. Seismological Research Letters, 76, 140-148.

Manetti G. 1457. De Terraemotu Libri Tres. Scopelliti, C. \& Molin, D. (eds) 1983, Rome.

Manning, S. W., Ramsey, C. B., Kuschera, W., Higham, T., Kromer, B., Steier, P. \& Wild, E. M. 2006. Chronology for the Aegean Late Bronze Age 1700-1400 BC. Science, 312, 565-569.

Manuel, F. E. 1959. The Eighteenth Century Confronts the Gods. Harvard University Press, Cambridge.

Masse, W. B. 1995. The celestial basis of civilization. Vistas in Astronomy 39, 463-477.

Masse, W. B. 1998. Earth, air, fire, and water: the archaeology of Bronze Age cosmic catastrophes. In: Peiser, B. J., Palmer, T. \& Bailey, M. E. (eds) Natural Catastrophes during Bronze Age Civilisations: Archaeological, Geological, Astronomical and Cultural Perspectives. BAR International Series 728, Archaeopress, Oxford, 53-92.

Masse, W. B. 2007. The archaeology and anthropology of Quaternary period cosmic impact. In Bobrowsky, P. \& Rickman, H. (eds) Comet Asteroid Impacts and Human Society. SpringerVerlag, London.

Masse, W. B. \& EspenaK, F. 2006. Sky as environment: solar eclipses and Hohokam culture change. In: DoYel, D. E. \& DeAN, J. S. (eds) Environmental Change and Human Adaptation in the Ancient Southwest. University of Utah Press, Salt Lake City, 228-280.

Masse W. B., Carter, L. A. \& Somers, G. F. (1991) Waha'ula heiau, the regional and symbolic context of Hawai'i Island's 'Red Mouth' temple. Asian Perspectives, 30, 19-56.

Masse, W. B., Johnson, R. K. \& Tuggle, H. D. 2007. Islands in the Sky: Traditional Astronomy and the Role of Celestial Phenomena in Hawaiian Myth, Language, Religion, and Chiefly Power. University of Hawaii Press, Honolulu. (In press).

NADDAF, G. 1998. Translator's introduction. In: Brisson, L. (ed.) Plato the Myth Maker. University of Chicago Press, Chicago, vii-liii.

National Geographic News 2005. Did Island Tribes Use Ancient Lore to Evade Tsunami? (January 25, 2005). Http://news.nationalgeographic.com/news/ 2005/01/0125 050125 tsunami island.html.

Nur, A., 1991, Earthquakes in the Bible. New Scientist, 1776, 45-48.

Palaephatus. 1996. On Unbelievable Tales (trans. Stern, J.). Bolchazy-Carducci Publishers, Wauconda, IL.

Patton, L. L. \& Doniger, W. (eds) 1996. Myth \& Method. University Press of Virginia, Charlottesville.

PicCARDI, L., 2000. Active faulting at Delphi: seismotectonic remarks and a hypothesis for the geological environment of a myth. Geology 28, 651-654.

PICCARDI, L. 2004. The rediscovery of Lernean Hydra's immortal head. Studi Geologici Camerti, Nuova Serie, 2, 131-139.
PICCARDI, L. 2005. Paleoseismic evidence of legendary earthquakes: the apparition of Archangel Michael at Monte Sant'Angelo (Italy). Tectonophysics, 408, 113-128.

PoPPER, K. 1972. Objective Knowledge: an Evolutionary Approach. Oxford University Press, New York.

RoHrbACHER, D. 2002. The Historians of Late Antiquity. Routledge, London.

RyAN, W. B. F. 2004. The Black Sea flood: a seed for myth? Paper 183-3 presented at the 32nd International Geological Congress, Florence, Italy.

Ryan, W. B. F. \& Pitman, W. C. III. 2000. Noah's Flood: The New Scientific Theories about the Event that Changed History. Simon \& Schuster, New York.

Rubin, D. C. 1995. Memory in Oral Traditions: The Cognitive Psychology of Epic, Ballads, and Counting-Out Rhymes. Oxford University Press, Oxford.

Schrempp, G. \& Hansen, W. 2002. Myth: A New Symposium. University of Indiana Press, Bloomington.

Segal, R. A. 1996. In: Patton, L. L. \& Doniger, W. (eds) 1996. Myth \& Method. University Press of Virginia, Charlottesville, 82-106.

Segal, R. A. 1999. Theorizing About Myth. University of Massachusetts Press, Boston.

Spiller, H. A., Hale, J. R. \& De Boer J. Z. 2002. The Delphic oracle: a multidisciplinary defence of the gaseous vent theory. Journal of Toxicology. Clinical Toxicology, 40, 189-196.

STERN, J. 1996 (trans.). Introduction. In: Palaephatus On Unbelievable Tales. Bolchazy-Carducci Publishers, Wauconda, IL 1-25.

Sturluson, S. 1971. The Prose Edda (trans. Young, J.). W.W. Norton, New York.

Vansina, J. 1985. Oral Tradition as History. University of Wisconsin Press, Madison.

VEYNE, P. 1988 (orig. 1983). Did the Greeks Believe in Their Myths? An Essay on Constitutive Imagination. (trans. Wissing, P.). University of Chicago Press, Chicago.

Vitaliano, D. B. 1973. Legends of the Earth: Their Geologic Origins. Indiana University Press. Bloomington.

VoGT, J. 1991. Some glimpses at historic seismology. Tectonophysics, 193, 1-7.

Von Hendy, A. 2002. The Modern Construction of Myth. Indiana University Press, Bloomington.

White, A. D. 1898. A History of the Warfare of Science with Theology in Christendom. D. Appelton \& Co., New York.

WyAtт, T. 1996. Geochronology and Myth—are Gods Catastrophes? CIESM Workshop Monograph 24: 'Human records of recent geological evolution in the Mediterranean Basin-historical and archaeological evidence', Santorini, 22-25 October 2003, 152 pp., Monaco.

Zdanowicz, C. M., Zielinski, G. A. \& Germani, M. S. 1999. Mount Mazama eruption: calendrical age verified and atmospheric impact assessed. Geology, 27, 621-624. 